\title{
РЕАКЦИОННАЯ СПОСОБНОСТЬ ОЗОНА \\ ПО ОТНОШЕНИЮ К НУКЛЕИНОВЫМ ОСНОВАНИЯМ В ВОДНЫХ РАСТВОРАХ
}

\author{
А.А. Максютова, Ю.С. Зимин \\ Химический факультет, Башкирский государственный университет, \\ 450076, Россия, Уфа, Заки Валиди, 32
}

DOI: 10.19163/MedChemRussia2021-2021-278

E-mail:ajm-ajms@mail.ru

В последние десятилетия значительно выросло применение озона в общей терапии болезней и косметологии. В то же время, использование озона способно приводить к окислению компонентов РНК, ДНК и, конечно же, нуклеиновых оснований (НО). В связи с этим актуальность приобретают исследования, которые направлены на изучение реакционной способности $\mathrm{O}_{3}$ по отношению к НО. Недавно [1, 2] получены первые результаты по кинетике озонированного окисления производных урацила. В настоящей работе изучена реакционная способность озона по отношению к четырем нуклеиновым основаниям - аденину, тимину, урацилу и цитозину - в водных растворах.

Исследования выполнены методом УФ-спектроскопии на приборе UV2600 фирмы «Shimadzu». На первом этапе определены коэффициенты экстинкции НО, использованные в дальнейшем для расчетов их остаточных концентраций. Далее, при равенстве начальных концентраций реагентов $\left([\mathrm{HO}]_{0}=\right.$ $\left.\left[\mathrm{O}_{3}\right]_{0}\right)$, изучена кинетика окисления нуклеиновых оснований озоном в водных растворах. Установлено, что кинетические кривые расходования исходных реагентов хорошо линеаризуются в координатах уравнения реакции второго порядка. Из опытов на барботажной установке следует, что на 1 моль НО приходится 1 моль $\mathrm{O}_{3}$. Таким образом, исследуемые реакции подчиняются кинетическому закону второго порядка (первого - по НО и первого - по О $)$ ). По интегральным уравнениям реакций рассчитаны константы скорости, значения которых свидетельствуют о сравнительно высокой реакционной способности озона по отношению к изученным основаниям.

В диапазоне температур 285-309 К исследована температурная зависимость констант скорости второго порядка. Обработка полученных результатов в логарифмических координатах уравнения Аррениуса позволила определить значения активационных параметров изученных реакций.

Исследование выполнено за счет гранта РНФ (проект № 19-73-20073).

\section{Литература}

[1] A.A. Maksyutova, Yu.S. Zimin, A.R. Gimadieva, and A.G. Mustafin, Russ. J. Phys. Chem. A. 2019, 93 (9), 1672-1676.

[2] А.А. Максютова, Е.Д. Моисеева, Ю.С. Зимин, и А.Г. Мустафин, Вест. БашГУ. 2020, 25 (2), 302-307. 